\section{Kidney \\ Blood Pressure \\ Research}

\title{
Cysteinyl 1 Receptor Antagonist Montelukast, Does Not Prevent Peritoneal Membrane Damage in Experimental Chronic Peritoneal Dialysis Model in Rats
}

\author{
Sibel Koçak Yucel ${ }^{\mathrm{a}}$ Hakki Arikan ${ }^{\mathrm{b}}$ Halil Tugtepe ${ }^{\mathrm{c}}$ Fulya Cakalagaoglud $^{\mathrm{d}}$ Serhan \\ Tuglulare Emel Akoglu ${ }^{f}$ Cetin Ozenerg
}

\begin{abstract}
aDivision of Nephrology, Department of Medicine, Bakırköy Dr. Sadi Konuk Training and Research Hospital; ${ }^{b}$ Department of Nephrology, Marmara University School of Medicine; 'Division of Pediatric Urology, Department of Pediatric Surgery, Marmara University School of Medicine, Istanbul; 'dAtaturk

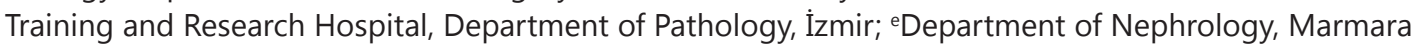
University School of Medicine; fDepartment of Nephrology, Academic Hospital; 9Department of Nephrology, Marmara University School of Medicine, Istanbul, Turkey
\end{abstract}

\section{Key Words}

Montelukast $\bullet$ Peritoneal membrane $\cdot$ Peritoneal dialysis $\bullet$ Cytokines

\begin{abstract}
Background/Aims: Continuous ambulatory peritoneal dialysis (CAPD) induces structural changes in the peritoneal membrane such as fibrosis, vasculopathy and angioneogenesis with a reduction in ultrafiltration capacity. Leukotriene (LT) receptor antagonists have been found to be effective to prevent fibrosis in some nonperitoneal tissues. The aim of this study is to investigate the possible beneficial effect of montelukast, a LT receptor antagonist, on peritoneal membrane exposed to hypertonic peritoneal dialysis in uremic rats. Methods: Of the 48 male, $5 / 6$ nephrectomized Wistar rats 29 remained alive and were included in the study. These studied rats were divided into 3 groups: Group I $(n=7)$ was the control group, Group II $(n=8)$ was treated with $20 \mathrm{ml}$ hypertonic PDF intraperitoneally daily and Group III was treated with montelukast and similar PDF treatment protocol. The morphological and functional changes in the peritoneal membrane as well as cytokine expression were compared between groups. Results: Submesothelial thickness and the severity of the degree of hyaline vasculapathy were more prominent in group III when compared to group I. There were no significant differences between group II and other groups in terms of submesothelial thickness and the severity of the degree of hyaline vasculapathy. Increased expressions of TGF- $\beta$ and VEGF in parietal peritoneal membrane were found in group II and group III when compared to group I. The
\end{abstract}




\section{Kidney Blood Pressure Research}

amount of TGF- $\beta$ and VEGF expression were similar in group II and group III. Conclusion: This study suggests that montelukast treatment does not prevent the peritoneal membrane from deleterious effects of hyperosmolar PDF in the uremic environment.

Copyright $\odot 2014$ S. Karger AG, Basel

\section{Introduction}

Peritoneal dialysis has developed into an effective renal replacement therapy for the treatment of the end-stage kidney disease. However, chronic peritoneal dialysis therapy can cause functional and structural peritoneal membrane abnormalities resulting in impaired dialysis efficiency and limited long-term usage. Peritoneal dialysis fluids (PDF) and recurrent peritonitis episodes damage the peritoneal membrane and induce peritoneal fibrosis [1]. The aspects of PDF defined as bioincompatible are the presence of glucose, low $\mathrm{pH}$, high lactate concentration and osmolality [2-4]. High glucose concentration with a corresponding rise in osmolality, the formation of glucose degradation products (GDP) and the accumulation of glycated proteins can be related to the derangements of cell functions [5-6]. The development of the morphologic vascular alterations in peritoneal ultrastructure also resembles diabetic microangiopathy [7-8].

In animal models, peritoneal transforming growth factor- $\beta$ (TGF- $\beta$ ), vascular endothelial growth factor (VEGF), angiogenic and fibrogenic growth factors, have been shown to correlate with peritoneal membrane function [9]. Increased peritoneal expression of TGF- $\beta$ and VEGF was associated with thickening of the submesothelial zone of the parietal peritoneum, increased angiogenesis, ultrafiltration failure and increased transport of solutes [10]. Interleukin 6 (IL-6) is a central mediator of the inflammatory response in the peritoneal cavity. Higher levels of intraperitoneal IL- 6 was produced with higher glucose concentration [11]. It was proposed that intraperitoneal IL-6 may be regarded as a marker of ongoing peritoneal inflammation [12].

Leukotriens (LTs) have proinflammatory properties including tissue edema [13], eosinophil migration [14], smooth muscle proliferation [15], monocyte activation [16] and chemotaxis [17]. There is some evidence that LT can play a role in peritoneal inflammation. Calcium ionophore A23187-stimulated peritoneal inflammatory cells produced significantly elevated amounts of LTB4 [18]. It has been shown that LTB4, LTC4 and LTD4 can enhance the production of IL-6 from cultured peritoneal macrophages of mice [19].

Cysteinyl LT antagonists have been successfully used in the treatment of asthma bronchiole, systemic mastoidosis, and interstitial cystitis in recent years [20]. The aim of the present study is to evaluate any potential effects of montelukast, a cysteinyl LT receptor antagonist, on the peritoneal membrane's functional and structural properties after exposure to PDS with high glucose concentration in chronic peritoneal dialysis in the uremic rat model.

\section{Subjects and Methods}

\section{Animals}

We used male Wistar rats (Marmara University, Istanbul, Turkey) that weighed 200 to $330 \mathrm{~g}$ at the start of the experiment. Rats were maintained under conventional laboratory conditions and were given free access to water and food. Body weights of all animals were monitored weekly, and no significant differences were found among the groups at the end of the experiment (Table 1). The Animal Research Ethics Board of Marmara University School of Medicine approved the experiment. 


\section{Kidney Blood Pressure Research}

posed through

a flank incision, and both the anterior and posterior poles and about one-third of the remaining cortical tissue from the exterior lateral part of the kidney were resected. One week later, the left kidney was removed after ligation of the blood vessels and ureter. After 5 weeks of subtotal nephrectomy, a peritoneal silicon catheter (Haidylena venous fistula set - 16G, $35 \mathrm{~mm}$, Lot No. 31316) was implanted. The lenght of the catheter was adapted to the rat's height and wedge-shaped holes were formed by scalpel on the distal $4-5 \mathrm{~cm}$ of the catheter. Omentectomy was not performed. The catheter was tunneled subcutaneously to an implant port on the back. After recovery, which was at least 1 week after catheter insertion, $20 \mathrm{ml}$ of warmed \%3.86 PDL (lactate-buffered glucose containing fluid; Dianeal, Baxter Healthcare) was given daily in the morning. Dwell time was 3 hours. Heparin (2500U/L), ceftazidim $(125 \mathrm{mg} /)$ and ciprofloxacin $(25 \mathrm{mg} / \mathrm{L})$ were added to all PDLs. Mupirocine was applied to the catheter exit site before exchange.

Rats were randomly divided into three groups. The control group (group I) (n=8) was not exposed to PDF but underwent operations for catheter implantation as well as nephrectomy. The second group (group II) ( $\mathrm{n}=10)$ was exposed to the $\% 3.86$ PDF for 4 weeks. The third group (group III) was exposed to the \%3.86 PDF and was given montelukast ( $4 \mathrm{mg} / \mathrm{kg}$ per day) for 4 weeks. Montelukast (Singulair $10 \mathrm{mg}$ pill, Merck Sharp \& Dohme, Whitehouse Station, NT, USA) was diluted with sterile saline to a final concentration of $4.0 \mathrm{mg} / \mathrm{ml}$ was administered by oral gavage under ether anesthesia. A 1-h peritoneal equilibration test (PET) was performed after 4 weeks to the PDF-treated animals as well as the controls (group A) by using $20 \mathrm{ml}$ of the \%2.27 PDL (lactate-buffered glucose containing fluid; Dianeal, Baxter Healthcare). Blood samples were taken from the tail vein at the start and end of the PET. The following day, the animals sacrificed $24 \mathrm{~h}$ after PET test and peritoneal tissues were taken for histopathological analysis, fixed in neutral buffered formalin, embedded in paraffin, sectioned, and stained for hematoxylin/eosin, Masson trichrome and Periodic Acid-Schiff (PAS) stains.

Urine, peritoneal and serum creatinine, BUN and glucose were determined by 917 automated chemistry (Boehringer Mannheim System, Roche).

\section{Histology}

Tissue samples were taken at sacrifice from the lower anterior abdominal wall distant from the site of catheter placement. Parietal peritoneum sections were fixed in a sufficient amount of $10 \%$ phosphatebuffered formaldehyde. The tissue samples were then paraffin processed, embedded and cut in $5 \mu \mathrm{m}$ sections. The cut sections were stained for hematoxylin/eosin, Masson trichrome and Periodic Acid-Schiff (PAS) stain. Each slide was examined at 10 random high-power (X400) views. An average of 10 independent measurements were calculated for each section. Mesothel cell numbers were scored semiquantitatively from 0 to $3+(0=$ none, $\mathrm{I}=$ mild, $\mathrm{II}=$ moderate, $\mathrm{III}=$ severe $)$ and mesothel cells were classified as normal (flat cells) and reactive (cubic transformation), (Figure 1). In PAS staining sections, hyaline vasculopathy were scored semiquantitatively as follows: Grade I, subendothelial hyaline material thickness (SEHMT) $<7 \mu$ m; Grade II, 


\section{Kidney \\ Blood Pressure Research}

Kidney Blood Press Res 2014;39:648-657

DOI: 10.1159/000368477

Publisned onIIne: December 19, 2014

(C) 2014 S. Karger AG, Basel

www.karger.com/kbr

Koçak Yucel et al.: Montelukast and Peritoneal Membrane

SEHMT > $7 \mu \mathrm{m}$ but no vascular lumen narrowing; Grade III, vascular lumen narrowing and distortion; Grade IV, vascular lumen obliteration. In Masson trichrome sections, fibrosis was graded as follows: no fibrosis, mild fibrosis (edema and a few collagen fibers), moderate fibrosis (young and mature collagen fibers) and severe fibrosis (mature collagen fibers). Submesothelial compact zone thickness was quantified by ocular micrometer and an average of 5 independent measurements was calculated for each rat and expressed in microns.

\section{Immunohistochemistry}

The following primary monoclonal antibodies were used: antiTGF- $\beta$ (Novocastra; NCLTGF- $\beta$; $1: 40$ ), anti-VEGF (C-1; sc-7269; Santa Cruz Biotechnology Santa Cruz Biotechnology) and antiIL-6 (M-19; sc-1265; Santa Cruz Biotechnology). Briefly, the slides were dewaxed using xylene, transferred to alcohol, placed in citric acid buffer $(10 \mathrm{mmol} / \mathrm{L})$ and heated in a microwave oven $(700 \mathrm{~W})$ for $15 \mathrm{~min}$ to expose antigens. Endogenous peroxidase activity was inhibited by incubating the section with $3 \%$ hydrogen peroxide in methanol for $5 \mathrm{~min}$. The slides were then washed three times with phosphate-buffered saline (PBS) and incubated with a Streptavidin-Peroxidase conjugate (Novostain Universal Detection Kit; NCL-RTU-D; Novocastra) for $10 \mathrm{~min}$ to reduce nonspecific antibody binding. After washing with PBS, the slides were incubated for $60 \mathrm{~min}$ with monoclonal antibodies. The reaction products were visualized with diaminobenzidine (DAB). The sections were counterstained with hematoxylin, dehydrated, and mounted. Immunexpressions of TGF- $\beta$, VEGF and IL- 6 were scored semiquantitatively from 0 to $3+$ ( $0=$ none, $\mathrm{I}=$ mild, $\mathrm{II}=$ moderate, $\mathrm{III}=$ =severe $)$

\section{Statistical Analysis}

All data is presented as median and 25-75th

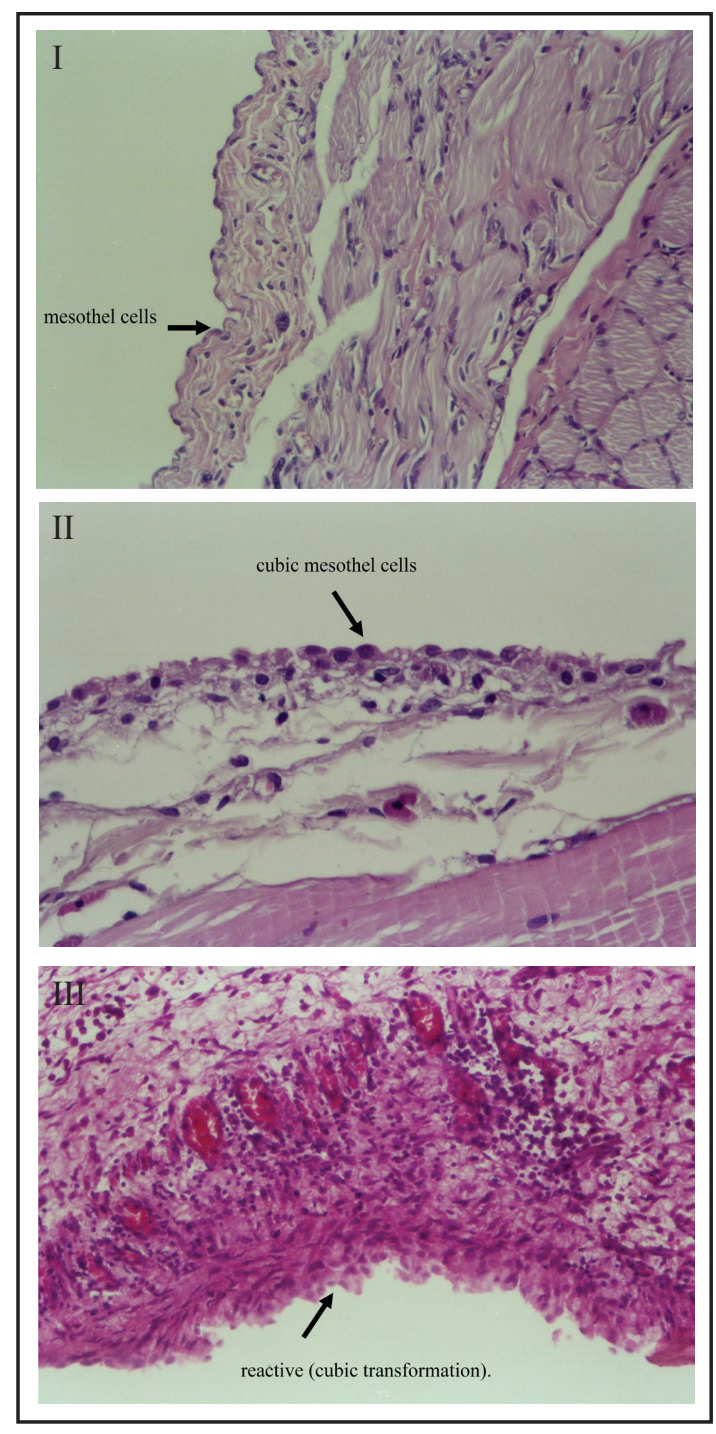

Fig. 1. Morphology of the peritoneum in group I: Control, Hematoxylin -Eosin (H\&E), 200X; II: Dextrose , H\&E;400X; and III: Montelukast, H\&E, 200X.

interquartile ranges. Unpaired data was analyzed using the non-parametric chi-square and Kruskal -Wallis tests. Multiple comparisons of paired data were made with nonparametric repeated-measures ANOVA with Friedman modification. All statistical analysis were performed using GraphPad Prism ${ }^{\mathrm{TM}} 2.00$ software (GraphPad Software, san Diego, CA). A p value $<0.05$ was considered significant.

\section{Results}

\section{Clinical Data}

Seven of 8 rats in group I, 8 of 10 rats in group II and 7 of 11 rats survived and remained for analysis after the 6th weeks of the study. The median serum BUN, creatinine levels at the baseline and at the study period are shown in Table 1. Chronic renal failure secondary to subtotal nephrectomy was characterized by higher urea and creatinine levels in all 


\section{Kidney Blood Pressure Research}

Table 2. Functional peritoneal membrane findings in group I, II and III.

\begin{tabular}{lccc}
\hline & $\begin{array}{c}\text { Group I } \\
(\mathrm{n}=7)\end{array}$ & $\begin{array}{c}\text { Group II } \\
(\mathrm{n}=8)\end{array}$ & $\begin{array}{c}\text { Group III } \\
(\mathrm{n}=7)\end{array}$ \\
\hline Protein concentration in dialysate $(\mathrm{g} / \mathrm{L})$ & $1(1-7)$ & $1.5(1-5)$ & $2(1-8)$ \\
Ultrafiltration $(\mathrm{ml})$ & $7(2-14)$ & $4(2-9)$ & $5(2-11)$ \\
$\mathrm{D} / \mathrm{P}$ urea $(\mathrm{mg} / \mathrm{dl})$ & $0.43(0.22-0.74)$ & $0.35(0.13-0.87)$ & $0.28(0.17-1)$ \\
$\mathrm{D}_{1} / \mathrm{D}_{0}$ glucose $(\mathrm{mg} / \mathrm{dl})$ & $0.11(0.08-0.17)$ & $0.12(0.08-0.21)$ & $0.07(0.06-0.13)$ \\
D/P creatinine $(\mathrm{mg} / \mathrm{dl})$ & $0.4(0.33-0.75)$ & $0.33(0.14-1)$ & $0.28(0.16-1)$ \\
\hline Data is expressed as medians with interquartile ranges. D, dialysate; P, plasma; $\mathrm{D}_{0}$ and $\mathrm{D}_{1}$, dialysate \\
at time 0 and at 1 hour during PET test, respectively.
\end{tabular}

Table 3. The comparison of histopathological findings of parietal peritoneal membrane in group I, II and III

\begin{tabular}{lccc}
\hline & $\begin{array}{c}\text { Group I } \\
(\mathrm{n}=7)\end{array}$ & $\begin{array}{c}\text { Group II } \\
(\mathrm{n}=8)\end{array}$ & $\begin{array}{c}\text { Group III } \\
(\mathrm{n}=7)\end{array}$ \\
\hline Mononuclear cell proliferation & $8(6-24)$ & $15.9(10-26)$ & $17.3(10-25)$ \\
Fibroblast proliferation & $6.3(4-15)$ & $9.3(7-15)$ & $12.3(6-17)$ \\
Angioneogenesis & $8.6(5-12)$ & $9.3(7-12)$ & $14.6(5.6-23)$ \\
Submesothelial thickness $(\mu \mathrm{m})$ & $10(10-30)^{\text {a }}$ & $30(10-100)$ & $40(20-100)$ \\
Hyaline vasculopathy & $1(1-1)^{\mathrm{b}}$ & $2(1-2)$ & $2(2-2)$ \\
Fibrosis & $1.5(1-2)$ & $2(1-3)$ & $2(1-3)$ \\
\hline $\begin{array}{l}\text { Data is expressed as medians with interquartile ranges. a group I vs group III, } \mathrm{p}<0.001 \text {; }^{\mathrm{b}} \text { group I vs } \\
\text { group III, } \mathrm{p}<0.05 .\end{array}$ & \multicolumn{3}{l}{} \\
\hline
\end{tabular}

groups before and after the PDF instillation for 4 weeks.

Four weeks after PDF instillation, a PET test was performed to all rats. The findings of PET test were summarized in Table 2. There were no differences in PET parameters in three groups.

\section{Histopathological Findings \\ Mesothelial cells were flat}

Table 4. Fibrosis scores in group I, II and III

\begin{tabular}{lccc}
\hline & $\begin{array}{c}\text { Group I } \\
(\mathrm{n}=7)\end{array}$ & $\begin{array}{c}\text { Group II } \\
(\mathrm{n}=8)\end{array}$ & $\begin{array}{c}\text { Group III } \\
(\mathrm{n}=7)\end{array}$ \\
\hline No fibrosis & $1(14.2)$ & - & - \\
Mild fibrosis & $3(42.9)$ & $3(37.5)$ & $1(14.2)$ \\
Moderate fibrosis & $3(42.9)$ & $4(50)$ & $4(57.2)$ \\
Severe fibrosis & - & $1(12.5)$ & $2(28.6)$ \\
The correlation between fibrosis and submesothelial thickness \\
$\mathrm{r}$ & 0.949 & 0.830 & 0.913 \\
$\mathrm{p}$ & $\mathrm{P}<0.005$ & $\mathrm{P}<0.05$ & $\mathrm{P}<0.005$ \\
\hline \multicolumn{4}{l}{} \\
\hline
\end{tabular}

in 6 rats and cubic shaped in 1 rat in group I (Control group) whereas they were flat in 6 rats in group II and in 1 rat in group III. Six of 7 rats treated with Montelukast (group III) showed cubic-shaped mesothelial cell morphology. Mononuclear cell and fibroblast proliferation as well as neovascularization were not significantly different between three groups. The histopathological comparisons of three groups are shown in Table 3. In group III, submesothelial thickness was much more than that of group I (40 $\mu \mathrm{m}$ (20-100) versus $10 \mu \mathrm{m}(10-30)$, respectively, $\mathrm{p}<0.05$ )) and more than group II. However, in group II, submesothelial thickness (30 $\mu \mathrm{m}(10-100)$ ) was not statistically different compared with other groups (Table 3$)$.

Hyaline vasculopathy was more prominent in group III than those in group I (2 (2-2) versus $1(1-1)$, respectively, $\mathrm{p}<0.001)$. In group II, the hyaline vasculopathy score was not statistically different from group I and group III. However, in group I all rats had grade I hyaline vasculopathy whereas 5 of 8 rats in group II have grade II hyaline vasculopathy. Consequently, hypertonic PDF exposure resulted in increased hyaline vasculopathy.

Fibrosis scores were not different between the three groups (Table 4). Montelukast treatment did not prevent the development of peritoneal fibrosis. Uremia and the presence of a catheter in the control group resulted in the least similar degree of fibrosis compared those with hypertonic glucose exposure. The degree of fibrosis was well correlated with 


\section{Kidney \\ Blood Pressure Research}

submesothelial thickness (Table 5). In group II, angioneogenesis was positively correlated with fibrosis and submesothelial thickness $(r=0.767, p<0.05 ; r=0.531$, $\mathrm{p}<0.05$, respectively. Angioneogenesis was also correlated with fibroblast proliferation in group III $(r=0.775, p<0.05)$.

\section{Immunohistochemical Findings}

The immune-expression scores of TGF- $\beta$, VEGF and IL- 6 in the three groups were shown in Table 6. In parietal peritoneal tissue sections, TGF- $\beta$ expression was more prominent in Group II (in 4 of 8 rats $(++)$, in 4 of 8 rats $(+++)$ expression) when compared with controls (in 6 of 7 rats $(+)$, in 1 of 7 rats $(++)$ expression), $(\mathrm{p}<0.005)$. TGF- $\beta$ expression was also significantly higher in group III (in 1 of 7 rats (+), 2 of 7 rats $(++)$ and 4 of 7 rats with $(+++)$ expression) than those with controls $(\mathrm{p}<0.005)$. (Figure 2). TGF- $\beta$ expression score was not significantly different between group II and III (Figure 3).
Table 5. The correlation between fibrosis and submesothelial thickness

\begin{tabular}{cccc}
\hline & $\begin{array}{c}\text { Group I } \\
(\mathrm{n}=7)\end{array}$ & $\begin{array}{c}\text { Group II } \\
(\mathrm{n}=8)\end{array}$ & $\begin{array}{c}\text { Group III } \\
(\mathrm{n}=7)\end{array}$ \\
\hline $\mathrm{r}$ & 0.949 & 0.830 & 0.913 \\
$\mathrm{p}$ & $\mathrm{P}<0.005$ & $\mathrm{P}<.05$ & $\mathrm{P}<0.005$ \\
\hline
\end{tabular}

Table 6. TGF- $\beta$, VEGF and IL-6 expression in group I, II and III

\begin{tabular}{lccc}
\hline & $\begin{array}{c}\text { Group I } \\
(\mathrm{n}=7)\end{array}$ & $\begin{array}{c}\text { Group II } \\
(\mathrm{n}=8)\end{array}$ & $\begin{array}{c}\text { Group III } \\
(\mathrm{n}=7)\end{array}$ \\
\hline $\begin{array}{l}\text { TGF- } \beta \text { expression } \\
(+)\end{array}$ & $6(85.7)$ & - & $1(14.3)$ \\
$(++)$ & $1(14.3)$ & $4(50)$ & $2(28.5)$ \\
$(+++)$ & - & $4(50)$ & $3(57.2)$ \\
VEGF expression & & & \\
$(+)$ & $5(71.5)$ & - & - \\
$(+)$ & $2(28.5)$ & $3(37.5)$ & $3(42.9)$ \\
$(+++)$ & - & $5(62.5)$ & $4(57.1)$ \\
IL-6 expression & & & \\
$(+)$ & $4(57.1)$ & $5(62.5)$ & $2(28.6)$ \\
$(++)$ & $3(42.9)$ & $3(37.5)$ & $3(42.8)$ \\
$(+++)$ & - & - & $2(28.6)$ \\
\hline
\end{tabular}

Data is expressed as medians (percentage). TGF- $\beta$

expression was lower in group I compared with group II and III $\left(\chi^{2}: 14.9, p<0,005\right)$. VEGF expression was higher in group II and III compared with group I $\left(\chi^{2}: 15.1\right.$,

$\mathrm{p}<0.005)$. IL-6 expression was similar in group I, II and III $\left(\chi^{2}: 5.2, p>0.05\right)$.
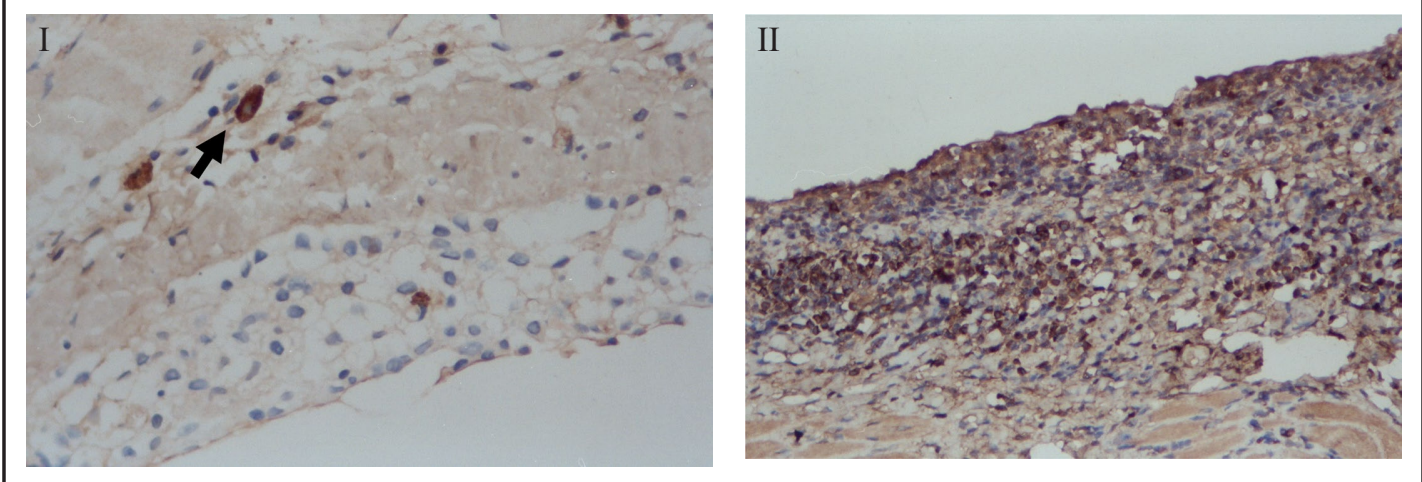

Fig. 2. The distribution of TGF- $\beta$ expression in group I: Control, +1 TGF- $\beta$ expression; $400 X$; and III: Montelukast, +3 TGF- $\beta$ expression; 200X.

In the control group, VEGF expression was less than those with group II and group III (in group I, 5 of 7 rats (+), 2 of 7 rats (++) expression; in group II, 3 of 8 rats $(++), 5$ of 8 rats with (+++) expression; in group III, 3 of 7 rats (++), 4 of 7 rats with (+++) expression), $(\mathrm{p}<0.05)$. There was no difference between group I and II in terms of VEGF expression. IL-6 expression scores were similar in all groups (Table 6). 


\section{Kidney Blood Pressure Research}

\section{Discussion}

In the current study, we found that submesothelial thickness and hyaline vasculapathy are more prominent in uremic rats exposed to hyperosmolar glucose lactate-buffered solution when compared to uremic rats not exposed to PDF. Subendothelial thickness was positively correlated with fibrosis as well. This finding demonstrates the harmful effect of hypertonic glucose solution on the peritoneal membrane. It is well recognized that hypertonic and acidic glucose solutions can induce structural changes in the peritoneal membrane including increased submesothelial zone thickness, extracellular matrix accumulation, fibrosis, angioneogenesis and hyaline vasculopathy [21-24]. Glucose triggers angiogenetic and profibrotic growth factors as well as cytokines resulting in fibrosis [25-27].

In the present study, hyaline vasculopathy was found to be more severe when the parietal peritoneum comes in contact with PDF. Previously, subendothelial hyalinization was found in $56 \%$ of PD patients whereas only in $28 \%$ of uremic subjects before dialysis. It was suggested that obliterative vasculopathy may cause ischemia leading to tissue fibrosis [22, 28]. Indeed, fibrosis was shown to have a positive correlation with hyaline vasculopathy.

The degree of angioneogenesis, fibrosis, fibroblast and mononuclear cell proliferation were not found to be significantly different between uremic rats with PDF and those without PDF. The duration of peritoneal dialysis and the degree of PDF exposition might have been insufficient to produce the difference. Peritoneal membrane permeability and structure changes including angioneogenesis, fibrosis and glucose degradation products (GDP) were also shown in the presence of uremia without dialysis [29].

TGF- $\beta$ and VEGF expression were also increased in parietal peritoneal tissue specimens in uremic rats exposed to hyperosmolar glucose lactate-buffered solution when compared to controls in our study. The impact of TGF- $\beta$ on the functional and structural properties of the peritoneal membrane was studied in previous studies [30-32].

Peritoneal mesangial cells induce fibroblast activation mediated by TGF- $\beta$ leading to matrix synthesis [33] and peritoneal fibrosis could be induced by TGF- $\beta$ in patients with long-term PD [34].

VEGF, a mitogen for endothelial cell and angiogenetic factor, is up-regulated in the vascular endothelium of the peritoneal membrane [35]. It was demonstrated that both high glucose and GDP in PDF induce VEGF production by cultured human peritoneal mesothelial cells (HPMC) [36]. Dialysate VEGF levels were found to be correlated with $\mathrm{D} / \mathrm{P}_{\text {creat }}$ as well as albumin and IgG clearances [12]. In our study, we did not demonstrate any relationship between PDF exposure or VEGF/ TGF- $\beta$ expression and peritoneal permeability which was evaluated by PET.

It was reported that $\mathrm{LTC}_{4}$ can produce lung fibroblast proliferation and collagen synthesis in rats [37] and up-regulate TGF- $\beta_{1}$ gene expression, which induces TGF- $\beta_{1}$ production by airway epithelial cells [38]. LTC $_{4}$ itself might have a proliferative action on fibroblasts [39]. In experimental studies, cys-LT receptor antagonism has protective effects in renal ischemia/ reperfusion injury [40], an antifibrotic effect in cyclosporine nephrotoxicity [39] and a 


\section{Kidney \\ Blood Pressure Research}

protective effect in bleomysin-induced pulmonary fibrosis by regulating the generation of inflammatory mediators [41]. Consequently, we hypothesized that cys-LT ${ }_{1}$ receptor blockage could have beneficial effects on the peritoneal membrane exposed to hyperosmolar PDF.

However, we did not observe any significant protective effect of montelukast, a cys-LT receptor antagonist, on the peritoneal membrane function or structure when it was exposed to hyperosmolar lactate-buffered acidic PDF in uremic rats with chronic peritoneal dialysis. Indeed, the montelukast treated rats had a similar degree of submesothelial thickness and hyaline vasculopathy as well as TGF- $\beta$ and VEGF expression when compared to those without montelukast therapy. The explanation of this observation was not clear when compared with other studies which were done on non-peritoneal tissues as mentioned before. The pathophysiologic role(s) of LTs in peritoneal dialysis has not been investigated extensively. In vitro incubation of peritoneal cell lines (polymorphonuclear cells, macrophages) in hypertonic dextrose solutions has resulted with not an increase but a decrease in the production of LTs [42]. Consequently, LTs may play a different or minor role in peritoneal tissue changes in subjects with PD compared with other pathologic conditions. Well-designed studies are needed to evaluate the pathophysiologic role of LTs on damaged peritoneal membranes in long-term peritoneal dialysis.

\section{Conclusion}

The present study suggests that cys-LT receptor antagonism does not protect the peritoneal membrane from the deleterious effects of PDF in the uremic environment.

\section{Disclosure Statement}

The authors declare that there is no conflict of interests regarding the publication of this paper.

\section{References}

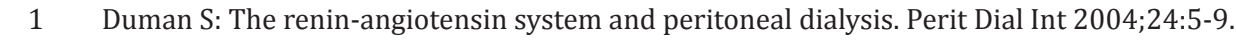

2 Devuyst 0, Margetts PJ, Topley N: The Pathophysiology of the peritoneal membrane. J Am Soc Nephrol 2010;21:1077-1085.

3 Di Paolo N, Garosi G, Monaci G, Brardi S: Biocompatibility of peritoneal dialysis treatment. Nephrol Dial Transplant 1997;12:S78-83.

4 Jörres A, Williams JD, Topley N: Peritoneal dialysis solution biocompatibility: inhibitory mechanisms and recent studies with bicarbonate-buffered solutions. Perit Dial Int 1997;17:42-46.

5 Tanna MM, Vonesh EF, Korbet SM: Patient survival among incident peritoneal dialysis and hemodialysis patients in an urban setting. Am J Kidney Dis 2000;36:1175-1182.

6 Breborowicz A, Rodela H, Karoń J, Martis L, Oreopoulos DG: In vitro simulation of the effect of peritoneal dialysis solution on mesothelial cells. Am J Kidney Dis 1997;29:404-409.

7 Di Paolo N, Sacchi G: Peritoneal vascular changes in continuous ambulatory peritoneal dialysis (CAPD): an in vivo model for the study of diabetic microangiopathy. Perit Dial Int 1989;9:41-45.

-8 Dobbie JW, Lloyd JK, Gall CA: Categorization of ultrastructural changes in peritoneal mesothelium, stroma and blood vessels in uremia and CAPD patients. Adv Perit Dial 1990;6:3-12.

\$9 Hekking LH, Zareie M, Driesprong BA, Faict D, Welten AG, de Greeuw I, Schadee-Eestermans IL, Havenith CE, van den Born J, ter Wee PM, Beelen RH: Better preservation of peritoneal morphologic features and defense in rats after long-term exposure to a bicarbonate/lactate-buffered solution. J Am Soc Nephrol 2001;12:27752786. 


\section{Kidney \\ Blood Pressure Research}

10 Linden T, Musi B, Järkelid L, Forsbäck G, Kjellstrand P, Deppisch R,Wieslander A: Glucose degradation products in peritoneal dialysis fluids may have both local and systemic effects: a study of residual fluid and mesothelial cells. Perit Dial Int 2001;21:607-610.

11 Pecoits-Filho R, Carvalho MJ, Stenvinkel P, Lindholm B, Heimbürger O: Systemic and intraperitoneal interleukin-6 system during the first year of peritoneal dialysis. Perit Dial Int 2006;26:53-63.

12 Pecoits-Filho R, Araújo MR, Lindholm B, Stenvinkel P, Abensur H, Romão JE Jr, Marcondes M, De Oliveira AH, Noronha IL: Plasma and dialysate IL-6 and VEGF concentrations are associated with high peritoneal solute transport rate. Nephrol Dial Transplant 2002;17:1480-1486.

13 Wasserman MA, Welton AF, Renzetti LM: Synergism exhibited by LTD4 and PAF receptor antagonists in decreasing antigen-induced airway microvascular leakage. Adv Prostaglandin Thromboxane Leukot Res 1995;23:271-273.

14 Muñoz NM, Leff AR: Blockade of eosinophil migration by 5-lipoxygenase and cyclooxygenase inhibition in explanted guinea pig trachealis. Am J Physiol 1995;268:446-454.

15 Porreca E, Di Febbo C, Di Sciullo A, Angelucci D, Nasuti M, Vitullo P, Reale M, Conti P, Cuccurullo F, Poggi A: Cysteinyl leukotriene D4 induced vascular smooth muscle cell proliferation: a possible role in myointimal hyperplasia. Thromb Haemost 1996;76:99-104.

$>16$ Woszczek G, Chen LY, Nagineni S, Shelhamer JH: IL-10 inhibits cysteinyl leukotriene-induced activation of human monocytes and monocyte-derived dendritic cells. J Immunol 2008;180:7597-7603.

17 Yokomizo T, Izumi T, Chang K, Takuwa Y, Shimizu T: A G-protein-coupled receptor for leukotriene B4 that mediates chemotaxis. Nature 1997;387:620-624.

18 Mansour MA, Al-Shabanah OA: Enhanced generation of leukotriene B4 from calcium ionophore-stimulated rat peritoneal inflammatory cells: a possible clinical relevance. Curr Drug Targets Inflamm Allergy 2003;2:4752.

19 Zhong M, Cheng G, Wang W, Zhou L, Zhu X, Zhang J: Effects of leukotrienes on production of interleukin 6 from mouse peritoneal macrophages. Yao Xue Xue Bao 1998;33:326-329.

20 Tolar J, Tope WD, Neglia JP: Leukotriene-receptor inhibition for the treatment of systemic mastocytosis. N Engl J Med 2008;350:735-736.

21 Margetts PJ, Kolb M, Yu L, Hoff CM, Holmes CJ, Anthony DC, Gauldie J: Inflammatory cytokines, angiogenesis, and fibrosis in the rat peritoneum. Am J Pathol 2002;160:2285-2294.

22 Willams JD, Craig KJ, Topley N, Von Ruhland C, Fallon M, Newman GR, Mackenzie RK, Williams GT; Peritoneal Biopsy Study Group: Morphologic changes in the peritoneal membrane of patients with renal disease. J Am Soc Nephrol 2002;13:470-479.

23 Krediet RT, Zweers MM, Van der Wal AC, Struijk DG: Neoangiogenesis in the peritoneal membrane. Perit Dial Int 2000;20:19-25.

-24 Mateijsen MA, van der Wal AC, Hendriks PM, Zweers MM, Mulder J, Struijk DG, Krediet RT: Vascular and interstitial changes in the peritoneum of CAPD patients with peritoneal sclerosis. Perit Dial Int 1999;19:517525 .

-25 Catalan MP, Reyero A, Egido J, Ortiz A: Acceleration of neutrophil apoptosis by glucose-containing peritoneal dialysis solutions: role of caspases. J Am Soc Nephrol 2001;12:2442-2449.

-26 Ha H, Cha MK, Choi HN, Lee HB: Effects of peritoneal dialysis solutions on the secretion of growth factors and extracellular matrix proteins by human peritoneal mesothelial cells. Perit Dial Int 2002;22:171-177.

27 Williams JD, Craig KJ, von Ruhland C, Topley N, Williams GT; Biopsy Registry Study Group: The natural course of peritoneal membrane biology during peritoneal dialysis. Kidney Int 2003;88:S43-49.

28 Combet S, Ferrier ML, Van Landschoot M, Stoenoiu M, Moulin P, Miyata T, Lameire N, Devuyst O: Chronic uremia induces permeability changes, increased nitric oxide synthase expression and structural modifications in the peritoneum. J Am Soc Nephrol 2001;12:2146-2157.

29 Margetts PJ, Kolb M, Galt T, Hoff CM, Shockley TR, Gauldie J: Gene transfer of transforming growth factorbeta1 to the rat peritoneum: effects on membrane function. J Am Soc Nephrol 2001;12:2029-2039.

-30 Ksiazek K, Korybalska K, Jörres A, Witowski J: Accelerated senescence of human peritoneal mesothelial cells exposed to high glucose: the role of TGF-beta1. Lab Invest 2007;87:345-356.

-31 Aguilera A, Yáñez-Mo M, Selgas R, Sánchez-Madrid F, López-Cabrera M: Epithelial to mesenchymal transition as a triggering factor of peritoneal membrane fibrosis and angiogenesis in peritoneal dialysis patients. Curr Opin Investig Drugs 2005;6:262-268. 


\section{Kidney \\ Blood Pressure Research}

-32 Nagy JA, Jackman RW: Anatomy and physiology of the peritoneal membrane. Semin Dial 1998;11:49-56.

33 Kumano K, Shimoda M, Hyodo T, Sakai T: The role of TGF-beta in growth inhibition of peritoneal mesothelial cells in high-glucose dialysate. Perit Dial Int 1995;15:93-95.

34 Kim CD, Kwon HM, Park SH, Oh EJ, Kim MH, Choi SY, Choi MJ, Kim IS, Park MS, Kim YJ, Kim YL: Effects of low glucose degradation products peritoneal dialysis fluid on the peritoneal fibrosis and vascularization in a chronic rat model. Ther Apher Dial 2007;11:56-64.

-35 Zweers MM, Struijk DG, Smit W, Krediet RT: Vascular endothelial growth factor in peritoneal dialysis: a longitudinal follow-up. J Lab Clin Med 2001;137:125-132.

-36 Ha H, Cha MK, Choi NH, Lee HB: Effects of peritoneal dialysis solutions on the secretion of growth factors and extracellular matrix proteins by human peritoneal mesothelial cells. Perit Dial Int 2002;22:171-177.

-37 Phan SH, McGarry BM, Loeffler KM, Kunkel SL: Binding of leukotriene C4 to rat lung fibroblasts and stimulation of collagen synthesis in vitro. Biochemistry 1988;27:2846-2853.

38 Perng DW, Wu YC, Chang KT, Wu MT, Chiou YC, Su KC, Perng RP, Lee YC: Leukotriene C4 induces TGF-beta1 production in airway epithelium via p38 kinase pathway. Am J Respir Cell Mol Biol 2006;34:101-107.

-39 Atakan A, Arikan H, Macunluoglu B, Tuglular S, Ulfer G, Cakalagaoglu F, Ozener C, Akoglu E: Renal protective effects of leukotriene receptor blockers in an experimental model of cyclosporine nephrotoxicity. Transplant Proc 2008; 40:279-284.

-40 Sener G, Sehirli O, Velioğlu-Oğünç A, Cetinel S, Gedik N, Caner M, Sakarcan A, Yeğen BC: Montelukast protects against renal ischemia/reperfusion injury in rats. Pharmacol Res 2006;54:65-71.

41 Izumo T, Kondo M, Nagai A: Cysteinyl-leukotriene 1 receptor antagonist attenuates bleomycin-induced pulmonary fibrosis in mice. Life Sci 2007;80:1882-1886.

42 Tzamaloukas AH: Peritoneal toxicities of hypertonic dextrose dialysate. Adv Perit Dial 1999;15:217-221. 